\title{
Hegemony and socialisation of the mass public: the case of postwar Japan's cooperation with the United States on China policy
}

\author{
QINGXIN KEN WANG
}

\begin{abstract}
The constructivism-inspired study on hegemony focuses on the dominant state's ability to shape the beliefs and values of ruling elites in secondary states as a basis of hegemony while paying less attention to the attitude of the mass public in secondary states toward hegemony and the effects of its 'socialisation' with hegemonic ideas. This article provides a conceptual framework for studying the relations between hegemony and the masspublic of secondary states and then subjecting it to a preliminary test against postwar Japan's cooperation with the United States on China policy.

The main argument of this article is that hegemony may be strengthened and maintained if the mass public of secondary states is socialised with hegemonic conceptions of world order, state identities and underlying ideologies, and acquires an independent constraint on hegemony. The mass public's socialisation with hegemonic ideas, which amounts to a cultural transformation in secondary states, may take place as a result of propagation by the dominant state and secondary state elites, or as a result of important international and domestic events caused by the hegemon, and then come to feed back on the political structures and processes of secondary states in ways conducive to the maintenance of hegemony. When hegemonic ideas are firmly embedded in the security culture of secondary states, ruling elites in those states may cooperate with the hegemon because they themselves genuinely embrace hegemonic ideas. More importantly, some ruling elites may cooperate with the hegemon out of political expediency as the hegemon-induced cultural transformation may change political structures and processes in such ways as to link the ruling elites' political legitimacy closely with secondary states' continued support for hegemony.
\end{abstract}

How hegemony is constituted and maintained has formed an important focus in the studies of international relations in the past two decades. Until recently, most attention has focused on disparate material conditions as the main basis of hegemony. Drawing on constructivism, scholars recently have identified a new source of hegemony that is ideational. It has been argued that hegemony can be maintained on the basis of ideological convergence between the dominant state and secondary states, as a result of the socialisation of ruling elites in secondary states with hegemonic ideologies. There is, however, a drawback to these recent studies. They tend to focus on the hegemon's ability to shape the beliefs and values of ruling elites in secondary states in gaining legitimacy for hegemony, while paying less attention to the attitude of the mass public in secondary states toward hegemony and the effects of its socialisation with hegemonic ideologies. More attention to the socialisation of the mass public in secondary states with hegemonic ideas and its effect on hegemony will not only enrich our understanding of hegemony but perhaps also shed some 
light on the origin and change of norms that are germane to the constructivist study of international relations.

How important is public disposition in secondary states toward hegemony? How does the mass public in secondary states socialise with hegemonic ideas? What factors are important in facilitating the mass public's socialisation? How may the mass public's socialisation with hegemonic ideas influence the stability of hegemony? These are the major questions to be examined in this article. The main argument of this article is that hegemony may be strengthened and maintained if the mass public of secondary states is socialised with hegemonic conceptions of world order, state identities and underlying ideologies, and acquires an independent constraint on hegemony. The mass public's socialisation with hegemonic ideas, which amounts to a cultural transformation in secondary states, may take place as a result of the propagation by the dominant state and secondary state elites, or as a result of important international and domestic events caused intentionally or unintentionally by the hegemon, and then come to feed back into the political process and become an independent constraint on hegemony. When hegemonic ideas are firmly embedded in the security culture of secondary states, ruling elites in those countries may cooperate with the hegemon because they themselves genuinely embrace hegemonic ideas. More importantly, some ruling elites may cooperate with the hegemon out of political expediency as cultural transformation initiated by the propagation of hegemonic ideas may change the political structures and processes in such ways as to link elites' political legitimacy closely with secondary countries' continued support for hegemony. Failure to cooperate with the hegemon may undermine their political legitimacy and jeopardise their political fortunes. In short, when hegemonic ideas are transmitted to, and become firmly embedded in, the security culture of secondary states, the hegemon acquires a subtle yet independent source of influence on the political process of secondary states, which may be conducive to the maintenance of hegemony on a more enduring basis despite the changes in international material conditions.

This article is divided into four sections. The first section provides a brief overview of recent constructivist conceptualisation of hegemony and its shortcomings. The second section introduces a framework of analysis to explore the effects of the mass public's socialisation with hegemonic ideas on hegemony. The third and fourth sections together provide a preliminary test of the framework by examining a case study, namely, the socialisation of the Japanese populace with American ideas in the postwar period and its effects on Japan's cooperation with the United States on China policy.

\section{The constructivist conception of hegemony}

As postulated by constructivists, states' identity and interest are endogenous to the international system and are determined and conditioned by intersubjective factors such as beliefs, values, identities and learning. ${ }^{1}$ Constructivists emphasise the power to produce intersubjective knowledge, or what is known as 'discursive power'. ${ }^{2}$

1 Ronald L. Jepperson, Alexander Wendt, and Peter J. Katzenstein, 'Norms, Identity, and Culture in National Security', in Katzenstein (ed.), The Culture of National Security:Norms and Identity in World Politics (New York: Columbia University Press, 1995), p. 40.

2 Ted Hopf, 'The Promise of Constructivism in International Relations Theory', International Security, 23: 1 (1998), pp. 178-80. 
For constructivists, hegemony is a type of hierarchical international order whereby the dominant state in the international system exercises transnational authority over secondary states. ${ }^{3}$ While constructivists recognise the importance of the material dimension in establishing hegemony, they tend to stress the ideational dimension of hegemony. ${ }^{4}$ In particular, constructivists believe that hegemony is founded largely on the legitimacy of hegemony in secondary states which entails the dominant state's manufacturing of a consenting identity for secondary states on the basis of hegemonic ideologies, and the propagation of these hegemonic ideas to secondary state elites. ${ }^{5}$ The acceptance of the hegemon's conceptions of world order and ideologies by secondary states legitimises hegemonic rule, provides a new basis for secondary states to redefine national identity and interest in accordance with those of the dominant state, and thus prolong hegemony even in the absence of coercion. ${ }^{6}$

The constructivist conception of hegemony has enriched our understanding of hegemony by highlighting the importance of the ideational source of power. Nonetheless, existing constructivist literature on hegemony has an important drawback. That is, it has paid little attention to the attitudes of the mass public in secondary states toward hegemony and the effects of the mass public's socialisation with hegemonic ideas on hegemony. It is assumed that ruling elites in secondary states can either suppress domestic opposition or manipulate public opinion. ${ }^{7}$

There are two reasons to believe why the mass public's attitudes toward hegemony deserve serious attention. First, public opinion may have an independent influence on foreign policy in any country. While ruling elites in secondary states may be able to suppress public opposition or manipulate public opinions, ruling elites may not have a totally free hand in imposing a pro-hegemonic foreign policy that contravenes the values and interests of the mass public, particularly when secondary states are democracies. ${ }^{8}$ Moreover, while governments may change public attitudes toward foreign policy, they may not be able to change public opinion in the way they want. Elites' manipulation of public opinion may lead to profound change in public opinion or the emergence of a new culture, which becomes resistant to further change. ${ }^{9}$

\section{A framework of analysis for the socialisation of the mass public}

Before I go on to examine the process by which the culture of military security can be transformed by the hegemon through the mass public's socialisation with hege-

3 Wendt, Alexander and Daniel Friedheim, 'Hierarchy under Anarchy: Informal Empire and the East German State', International Organization, 49: 4 (1995), p. 695.

4 See Wendt and Friedheim, 'Hierarchy under Anarchy', pp. 696-8. John G. Ikenberry and Charles A. Kupchan, who may not identify themselves as constructivists, have made similar arguments. See Ikenberry and Kupchan, 'Socialization and Hegemonic Power', International Organization, 44: 3 (1990), p. 293.

5 Ikenberry and Kupchan, 'Socialization and Hegemonic Power', pp. 289-92. For a similar argument, see Michael Doyle, Empire (Ithaca, NY: Cornell University Press, 1986), pp. 228-9.

6 Wendt and Friedheim, 'Hierarchy under Anarchy', pp. 700-5. Also Scott C. James and David A. Lake. 'The Second Face of Hegemony: Britain's Repeal of the Corn Laws and the American Walker Tariff of 1846', International Organization, 43: 1 (1989), p. 4.

7 Ikenberry and Kupchan, 'Socialization and Hegemonic Power', p. 293; and Wendt and Friedheim, 'Hierarchy under Anarchy', p. 706.

8 Kennthe Boulding, 'National Images and International Systems', in James Rosenau (ed.), International Politics and Foreign Policy (New York: The Free Press of Glencoe,1961), p. 392.

9 Charles Kupchan, The Vulnerability of Empire (Ithaca, NY: Cornell University Press, 1994), 
monic ideas, it is necessary to define the concept of the culture of military security. For the purpose of this article, I am concerned with a category of collectively-shared beliefs, values and images that are political or philosophical in nature, but have great bearing on a state's military security and appropriate strategy and tactics. For the lack of a better word, I use the term 'culture of military security' to describe these ideational components and will use it interchangeably with security culture. Thus, the culture of military security is defined as a state's collectively-held beliefs about how domestic political order and international order are constituted, images about the international system and the identities of its own and other states in the international system, and beliefs about the efficacy of force in constructing international order. ${ }^{10}$ These security-related beliefs and ideas may inform policymakers as to the nature of international conflict, how international order is to be constructed to attain national security and whether or not force should be used to resolve international conflict. Beliefs about domestic political order are included in the culture of military security because they may also shape individuals' images about state identities and international order. ${ }^{11}$

\section{How the mass public may be socialised with hegemonic ideas}

Hegemonic ideas, like any new ideas, when diffused to the population in secondary states, will inevitably generate a lot of resistance as they may clash with traditional values and beliefs which may have been firmly embedded in the belief systems of the population through other more intimate sources of the socialisation process such as family and school. ${ }^{12}$ The diffusion of hegemonic ideas to the societies of secondary states can be a prolonged process of ideational contestation between foreign ideas and indigenous ideas. When favourable conditions are present, hegemonic ideas, like any norms in the norm-building process, may 'cascade' to a large number of societal actors and become eventually internalised by the mass public of secondary states. ${ }^{13}$

Why then may the mass public be inclined to accept hegemonic ideas? What factors are conducive to the mass public's socialisation with hegemonic ideas? As early as 1965, Karl Deutsch and Richard L. Merritt had identified three factors, governmental policy, spectacular events, and cumulative events, as important in inducing cultural change. ${ }^{14}$ Likewise, recent constructivist studies have identified

10 This definition draws on Boulding, 'National Images and International Systems', pp. 390, 392. Also Herbert C. Kelman, 'Social-Psychologial Approaches to the Study of International Relations: Definition of Scope', in Kelman (ed.), International Behavior: A Social-Psychological Analysis (New York: Holt, Rinehart and Winston, 1965), p. 24. The concept of security culture is similar in some ways to Thomas U. Berger's concept of political-military culture. See Berger, 'Norms, Identity and National Security in Germany and Japan', in Katzenstein (ed.), The Culture of National Security, pp. 325-6. But the notion of security culture differs from Berger's in that security culture includes images of domestic order, national identities and international order.

11 Jepperson, Wendt, and Katzenstein, 'Norms, Identity, and Culture in National Security', pp. 52-9. Also Kelman, 'Social-Psychologial Approaches to the Study of International Relations: Definition of Scope', pp. 26-7.

12 Boulding, 'National Images and International Systems', pp. 392.

13 Martha Finnemore and Kathryn Sikkin, 'International Norm Dynamics and Political Change', International Organization, 52: 4 (1998), p. 896.

14 Karl W. Deutsch and Richard L. Merritt, 'Effects of Events on National and International Images', In Kelman, International Behavior, pp. 169-74. 
similar factors in norm-building and fostering cultural change. They can be roughly grouped into two categories: human agency and external events. ${ }^{15}$ The process of cultural change fostered by the hegemon should be similar to the process of cultural change in general and norm-building in particular. Drawing on these studies, we can identify two major factors, governmental policy and external events, as important in inducing the mass public's socialisation with hegemonic ideas.

First, the population may be socialised with hegemonic ideas under intense official propagation initiated by either the dominant state or ruling elites in secondary states. The dominant state may be motivated to propagate its ideas and values as it wants to rationalise hegemony and gain domestic legitimacy for hegemony in secondary states. Similarly, ruling elites in secondary states may want to propagate hegemonic ideas and beliefs to the society in order to rationalise hegemony, as supporting hegemony may undermine national sovereignty and autonomy and jeopardise the political credibility of secondary state elites. Ruling elites in the dominant state or secondary states may act as what Martha Finnemore and Kathryn Sikkink call 'norm entrepreneurs' to facilitate the population's socialisation with hegemonic ideas and foster cultural change in secondary states. ${ }^{16}$ The belief systems of the masses are vulnerable to propaganda and manipulation by secondary state elites and the hegemon for two reasons. First, the belief systems of the masses are fragmented and sometimes confused in the absence of accurate information. In contrast, ruling elites have more access to information and their ideas and beliefs tend to be derived from causal suppositions and coherent inference. ${ }^{17}$ Moreover, the dominant state and secondary state elites are in a unique position to change public opinion, as they possess and even monopolise the legitimate means of sanctions such as material inducements and coercive mechanisms. ${ }^{18}$ The dominant state and secondary states can manipulate public opinion through censorship, dissemination of official policy speeches, or educational programs. ${ }^{19}$ Thus the mass public in secondary states may be induced to internalise hegemonic ideas and make their beliefs conform more closely to governmental policy. ${ }^{20}$

Second, external events may also induce the mass public's socialisation with hegemonic ideas independently of governmental policy and official propaganda. Hegemonic ideas may be embraced by the mass public of secondary states when the population experiences what Deutsch and Merritt called 'spectacular events' (that is, international or domestic crises, war, revolution) or 'cumulative events' (such as continued economic growth or population growth trends, or a wave of successive low-intensity conflicts). ${ }^{21}$

When countries undergo a period of enormous political or economic turmoil, traditional as well as indigenous values and beliefs in these countries may be called

15 Paul Kowert and Jeffrey Legro, 'Norms, Identity, and Their Limits: A Theoretical Reprise', in Katzenstein, The Culture of National Security, pp. 469-83; Finnemore and Sikkink, 'International Norm Dynamics and Political Change', p. 896.

16 Finnemore and Sikkink, 'International Norm Dynamics and Political Change', pp. 896-7.

17 Charles Kupchan, Vulnerability of Empire, p. 89.

18 For similar arguments, see Doyle, Empire, p. 41.

19 Deutsch and Merrit, 'Effects of Events on National and International Images', pp. 138-9. Also see Finnemore and Sikkink, 'International Norm Dynamics and Political Change', pp. 899-901.

20 Finnemore and Sikkink, 'International Norm Dynamics and Political Change', p. 904.

21 Sidney Verba, 'Conclusion: Comparative Political Culture', in Lucian W. Pye and Sidney Verba (eds.), Political Culture and Political Development (Princeton, NJ: Princeton University Press, 1965), p. 555. 
into question. New and prominent ideas, such as hegemonic ideas, will more likely be accepted as the populace embarks on a search for a new cultural or moral compass when experiencing a loss of cultural orientation. ${ }^{22}$

Cumulative events, taken in isolation, may not have a significant impact on the belief systems of the people because of their low intensity. But when similar events recur over a certain period of time, or certain trends increase in scope and intensity, they may induce the population in secondary states to accept hegemonic ideas in the same way as spectacular events. ${ }^{23}$

While each of these factors, official propagation, spectacular or cumulative events, may act independently to facilitate the population's socialisation with hegemonic ideas, the impact of each factor alone on cultural change may be quite limited. The population's socialisation with hegemonic ideas may be most likely to happen when more than one of these factors come together and are reinforcing each other. In the words of Deutsch and Merritt, 'where ... the spectacular action of a government paralleled a predominant trend within its own society and at the same time did not encounter frustrating difficulties in the international environment, it could indeed reinforce and restructure major images of a large part of the population' ${ }^{24}$

Thus, the hegemon may be in a unique position to bring about cultural change in secondary states as the hegemon distinguishes itself from ordinary states in its possession of preponderant material power and its greater ability to generate, control, shape and interpret both spectacular as well as cumulative events such as winning a major war, dropping an atomic bomb, maintaining a prolonged period of international peace or stimulating economic recovery in secondary states. Moreover, the government of the dominant state also distinguishes itself in its ability to have a strong influence on the governments of secondary states. If the hegemon, in collaboration with governments of secondary states, can generate, control, or shape events in ways that make the experiences of the population in secondary states congruent with hegemonic ideologies, or provide an interpretation about events to help the mass public make sense of what is happening around them, the hegemon may acquire an unique ability to induce the mass public of secondary states to embrace hegemonic ideas and produce cultural change in the country.

While the security-related beliefs of the mass public may be vulnerable to manipulation by governments to a certain extent, and receptive to environmental changes under certain conditions, once transformed, they may develop a life of their own and constitute a new culture of military security. The new security culture may be very resistant to change for a long period of time as it may be passed on to a new generation through socialisation without critical examination. ${ }^{25}$

When hegemonic ideas are embedded in the security culture of secondary states, the policymaking process of secondary states may be constrained in two ways. ${ }^{26}$ First, elites themselves in secondary states, like the population, may internalise new cultural values and state identities informed by hegemonic ideas and become emotionally and cognitively committed to the fulfilment of new state identities and

22 Clifford Geertz, 'Ideology as a Cultural System', in David E. Apter (ed.), Ideology and Discontent (New York: The Free Press, 1964), pp. 63-4.

23 Deutsch and Merritt, 'Effects of Events on National and International Images', p. 136.

24 Ibid, p. 172.

25 For a similar observation, see Kupchan, The Vulnerability of Empire, pp. 70-94.

26 For similar arguments, see ibid, p. 95. 
goals. As has been widely recognised, elites in secondary states may thus define national interests and frame policy debates on the basis of a new cultural orientation in ways that prolong hegemony. ${ }^{27}$

Moreover, the embeddedness of hegemonic ideas in the security culture of secondary states may have an important implication for the maintenance of hegemony which has hitherto received little attention. That is, some ruling elites in secondary states may be compelled by the shifts in the security culture to continue supporting hegemony out of political expediency even though they themselves may not genuinely believe in hegemonic ideas. ${ }^{28}$ This is because, as Lucian Pye observes, political culture provides order and form for political structures and processes, and changes in political culture inevitably cause changes in these political structures and processes. Likewise, as Gabriel Almond suggests, 'every political system is embedded in a particular pattern of orientation to political action'. ${ }^{29}$ The entrenchment of hegemonic ideas in the population of secondary states means that the hegemonic conceptions of world order, images of state identities and their underlying ideologies may infuse the public political disposition, reorient the intellectual paradigms and central values of most ruling elites, redefine the organisational goals and interests of the elite institutions and bureaucracy, and in effect create a balance of political forces in the elite community as well as in the population, toward favouring the maintenance of hegemony. In other words, some ruling elites may be compelled to continue to support hegemony because their domestic legitimacy is closely linked with hegemony even though they themselves may not embrace hegemonic ideas.

To summarise, four hypotheses can be derived from the above. First, governmental policies in both the dominant state and secondary states may be an important factor in inducing the mass public to internalise hegemonic ideas. Second, significant external events may be another important factor that can induce the mass public's socialisation with hegemonic ideas. If governmental policy and external events come together to reinforce each other, they may create effective conditions for the mass public's socialisation with hegemonic ideas and produce a most powerful cultural change. Third, the internalisation of secondary states' mass public with hegemonic ideas, such as hegemonic conceptions of world order, state identities and their underlying ideologies, may transform the political structures and processes of secondary states. Fourth, the political changes caused by the hegemon-induced cultural change may contribute to the maintenance of hegemony independent of the material conditions that gave rise to hegemony in the first place.

\section{The United States and the transformation of postwar Japan's culture of military security}

This section is the first part of a preliminary test of the hypotheses formulated above through examining the Japanese mass public's socialisation with the American

27 Wendt and Friedheim, 'Hierarchy under Anarchy', pp. 700-5.

28 Doyle, Empire, p. 37.

29 See Lucian W. Pye, 'Introduction: Political Culture and Political Development', in Pye and Verba, Political Culture and Political Development, p. 7. Also Gabriel A. Almond, 'Comparative Political System', in Heinz Eulau, et al. (eds.), Political Behavior: A Reader in Theory and Research (Glencoe, IL: The Free Press, 1956), pp. 34-42. 
conception of postwar world order and underlying ideologies, and its effect on American hegemony. It purports to show how both American material and normative powers, and external events that America helped to bring about, have led to the Japanese mass public's socialisation with American ideas and consequently cultural and political changes in Japan.

\section{Changes in American policy visions toward postwar Japan}

American foreign policy objectives immediately after the occupation of Japan rested on a structural theory which attributed Japanese military aggression to the 'feudalistic' nature of Japanese society and hence that the main mission of American occupation was to rid Japan of the remnants of Japanese feudalism. This theory was reflected in the succinct statement by Assistant Secretary of State Dean Acheson in September 1945 that 'the present economic and social system in Japan which makes for a will to war will be changed so that the will to war will not continue'. ${ }^{30}$ This theory was translated into two concrete policy objectives in Japan: demilitarisation and democratisation, which were to be implemented by the SCAP (Supreme Commander for Allied Powers) in Japan in the next two years. ${ }^{31}$

Just one month after the Japanese surrender, the SCAP issued an order banning the teaching of all militaristic and ultra-nationalistic ideologies in schools and purging teachers associated with such ideologies. ${ }^{32}$ Censorship was employed against the Japanese literary works which exhibited the tendency of exalting feudal virtues. ${ }^{33}$ To further uproot Japanese ultra-nationalism, the SCAP undertook a large-scale political purge. ${ }^{34}$ The SCAP's democratic reforms in Japan culminated in the rewriting of the constitution in 1947. To prevent Japan from becoming a military threat to the world again, article 9 of the constitution explicitly prohibits Japan from waging war as an instrument of foreign policy. ${ }^{35}$ General MacArthur, the most powerful man in Japan during the occupation, personified the American official conception of a new Japan as a pacifist, westernised and dependent ally of the United States at this period. As he believed, the elimination of the Japanese military threat entailed more than the dismantling of Japanese war machinery, it entailed the fundamental transformation of Japanese cultural identity through democratisation and even the spread of the Christian faith in Japan. Japan would re-emerge on the world stage with a distinctly Western and pacifist identity. Moreover, MacArthur was not ready to leave Japan completely neutral and adrift. In his own words, through westernis-

30 John Dower, 'Reform and Reconsideration', in Harry Wray and Hilary Conroy (eds.), Japan Reexamined: Perspectives on Modern Japanese History (Honolulu, HI: University of Hawaii Press, 1983), pp. 345-6.

31 Michael Schaller, The American Occupation of Japan: the Origins of the Cold War in Asia (New York: Oxford University Press, 1985), ch. 2.

32 I. I. Morris, Nationalism and the Right Wing in Japan: A Study of Postwar Trends (London: Oxford University Press, 1960), pp. 2-3.

33 Meirion Harries and Susie Harries, Sheathing the Sword: The Demilitarization of Japan (London: Hamish Hamilton, 1987), ch. 7.

34 Gerald Curtis, The Japanese Way of Politics (New York: Columbia University Press,1988), p. 6.

35 Dower, 'Reform and Reconsideration, pp. 345-6. 
ation, the new Japan would form the 'Western outpost of our defense' guaranteed by American military power. ${ }^{36}$

The SCAP's reformist vision of postwar Japanese identity was soon subject to revision as the Cold War intensified. The communist victory on the Chinese mainland gradually led the Truman Administration to rethink American strategic policy toward Asia. A new state identity for Japan was conceived by the Truman Administration as a result of the policy revision. Japan was to play a more active role as a strategic ally of the United States in its emerging global power struggle with the Soviet Union. To make Japan impervious to communism, the Truman administration began to emphasise the restoration, rather than the weakening, of Japanese industrial and military strength, so as to make Japan a cornerstone of American containment strategy in East Asia. ${ }^{37}$ The so-called 'reverse course' in American policy toward Japan greatly strengthened the Japanese conservative parties and laid an important foundation for American hegemony in Japan.

\section{The Yoshida Doctrine and the US-Japan peace settlement}

The fall of China to communism and the subsequent outbreak of the Korean War in the summer of 1950 heightened the urgency for the Truman Administration of concluding an early peace settlement with Japan, and led to the emergence of a unified American policy to push for such a settlement. ${ }^{38}$ The Japanese on all sides of the political spectrum had all along favoured an early peace settlement and a quick end to the occupation so as to restore Japanese national pride. Nonetheless, they differed widely about Japan's state identity and purpose after the occupation. Three different conceptions about postwar Japan's state identity and purpose were articulated respectively by three different political forces, the leftists, the right conservatives, and centrist conservatives. Japan's security after occupation was at the centre of the debate in light of the intensifying Cold War conflict.

The leftists, who formed the bulk of the Japan Socialist Party (JSP) and the Japan Communist Party (JCP), embraced the Marxist worldview and aspired to build socialism in Japan. They embraced the American reformist theory that the remnants of Japan's feudalism was a direct cause of the rise of Japanese militarism in the 1930s and 1940s and saw the SCAP's political reforms as indispensable to eradicating Japanese feudalism. As they believed, Japan's unarmed neutrality was the best option to guarantee Japan's physical security after the restoration of its sovereignty, as Japan's embroilment in the Cold War conflict might lead to Japan's rearmament and a breach of the pacifist constitution. They also wanted Japan to negotiate an overall peace settlement with all of its former enemies. The conservatives on the right, who included the bulk of the Democratic Party and a major faction of the

36 Schaller, The American Occupation of Japan, pp. 69-70.

37 John Gaddis, Strategy of Containment: A Critical Appraisal of Postwar American National Security Policy (New York: Oxford University Press, 1982), pp. 37-45.

38 Richard B. Finn, Winners in Peace: MacArthur, Yoshida and Postwar Japan (Berkeley, CA: University of California Press, 1992), p. 245. 
Liberal Party led by Aishida Hitoshi and Hatoyama Ichiro respectively, had a strong attachment to the Japanese tradition and were staunchly nationalist. They opposed the American-authored constitution and especially Article 9, which they felt had compromised Japan's sovereign rights and security. Alarmed by the Korean War, they believed that Japan's state identity and security after the end of occupation lay in the restoration of Japanese national greatness through revising the constitution and immediate large-scale rearmament. ${ }^{39}$

The centrist conservatives, who formed the bulk of the Liberal Party led by Yoshida Shigeru, held a middle-of-the-road vision for Japan's future destiny which juxtaposed both the early and later American conceptions of world order and Japanese identities. Yoshida did not support Japan's immediate rearmament on a large scale as the rearmament would inevitably drain its limited resources and retard economic recovery. ${ }^{40}$ Nor did Yoshida support Japan's neutrality in the Cold War conflict. Instead, Yoshida advocated a national policy programme for postwar Japan that would lay the foundation for Japan's national policy and purpose after the restoration of her sovereignty: Japan should be integrated into American hegemony while concentrating on its economic reconstruction and minimising its military involvement in world affairs. The so-called Yoshida Doctrine entailed the dramatic transformation of Japanese state identity. That is, Japan would be a pacifist member of the Western anticommunist alliance led by the United States. ${ }^{41}$ On this basis, the Yoshida government and the Truman administration concluded a peace treaty in San Francisco in September 1951, along with a security treaty committing the United States to defend Japan in exchange for the continued stationing of American troops there. $^{42}$

The emergence of a new culture of military security in Japan

Shortly after the conclusion of the San Francisco Peace Treaty, the pro-American foreign policy vision embodied in the Yoshida Doctrine became the focus of political attacks and protests among the public. The Japanese public was critical of Yoshida's policy vision and saw it as a sell-out of Japan's sovereign rights. ${ }^{43}$ Japan's neutrality versus alignment in world politics soon became the center of political contention as politicians from both the Left and the Right sought to capitalise on the public disenchantment with the Yoshida doctrine. The conservatives from the right led by Hatoyama and his close associates who were 'depurged' as a result of the 'reverse

39 Masumi Junnosuke, Contemporary Politics in Japan (Berkeley, CA: University of California Press, 1995), pp. 215-16.

40 John Dower, Empire and Aftermath: Yoshida Shigeru and the Japanese Experience: 1878-1954 (Cambridge, MA: Harvard University Press, 1979), pp. 377-99.

41 Yoshida Shigeru, The Yoshida Memoirs (Westport, CT: Greenwood Press, 1961), pp. 8-9, 28. Also see Mike Mochizuki, 'Japan's Search for Strategy', International Security, 8: 3 (Winter 1983/1984), pp. 152-89; and Kenneth B. Pyle, The Japanese Question: Power and Purpose in a New Era (Washington, DC: The AEI Press, 1992), chs. 3 and 4.

42 Martin Weinstein, Japan's Postwar Defense Policy, 1947-1968 (New York: Columbia University Press, 1971), p. 62 and Appendix A.

43 Dower, Empire and Aftermath, p. 371. 
course', mounted a more fierce challenge to the Yoshida line from within the Liberal Party. The ideological polarisation in the political world and among the mass public culminated in the security treaty crisis of 1960, which resulted in the downfall of the Kishi government when the government renewed the security treaty. ${ }^{44}$ The security treaty crisis of 1960 taught every Japanese a valuable lesson about the importance of ideological compromise for the sake of maintaining political stability. ${ }^{45}$ Subsequent governmental policies of Japan and the United States, coupled with cumulative changes in domestic economic conditions and international environments, provided the critical mass for the Yoshida doctrine to be accepted by the majority of the Japanese political elites and populace.

The new government headed by Ikeda Hayato, a protégé of Yoshida, set out to reunite the Japanese with a new national purpose embodied in the Yoshida doctrine. He adopted the famous 'income doubling plan' as the new top policy priority and kept a low profile (tei shisei) for Japan's foreign affairs. ${ }^{46}$ The large-scale public protests against the Vietnam War prompted the Sato government to declare in 1967 that Japan would neither become a nuclear power nor export arms. ${ }^{47}$ Ikeda's and Sato's centrist programmes gradually bore economic fruit for the ordinary Japanese as they translated into double-digit economic growth from the mid-1960s and rising living standards for ordinary citizens, thus further increasing Japanese popular support for the US-Japan alignment. The United States was indirectly responsible for the transformation of the Japanese attitudes toward the security treaty as it deliberately cultivated Japanese popular support for the centrist governments through increasing economic assistance and trade market access to Japan. ${ }^{48}$ The reversion of Okinawa to Japan in the early 1970s further dampened Japanese nationalism and strengthened the popular support for the Yoshida doctrine. ${ }^{49}$ The Okinawa reversion and the winding down of the Vietnam War thus further helped the debate on the US-Japan security treaty 'to lose its central place in Japanese politics in the 1970s and the 1980s', to use the words of former US ambassador to Japan, Edwin Reischauer. ${ }^{50}$

The dramatic changes in Japan's popular attitudes toward democracy, peace and alignment, and the emergence of a new Japanese security culture centred around the Yoshida doctrine, have been well documented. ${ }^{51}$ As Table 1 shows, more and more Japanese believed that the constitution was good and did not need revision, suggesting Japanese acceptance of Japan's identity as a democratic state. The

\footnotetext{
44 George Packard, Protest in Tokyo: The Security Treaty Crisis of 1960 (Princeton, NJ: Princeton University Press, 1966).

45 Kosaka Masakata, 100 Million Japanese (Tokyo: Kodansha International, 1972), pp. 199-201.

46 Ibid, pp. 200-5.

47 Pyle, The Japanese Question, pp. 32-4.

48 Michael Schaller, Altered States: The United States and Japan Since the Occupation (New York: Oxford University Press, 1997), p. 169.

49 Reischauer, The Japanese Today: Change and Continuity (Cambridge, MA: Belkrap Press, 1988), p. 360; Schaller, Altered States, pp. 213-14.

50 Reischauer, The Japanese Today, p. 361.

51 Davis B. Bobrow, 'Japan in the World: Opinion from Defeat to Success', Journal of Conflict Resolution, 33: 4 (December 1989). Thomas U. Berger, 'From Sword to Chrysanthemum: Japan's Culture of Anti-militarism', International Security, 17: 4 (Spring 1993), and 'Norms, Identity and National Security in Germany and Japan', pp. 325-6. Also Kenneth B. Pyle, 'The Future of Japanese Nationality: An Essay in Contemporary History', Journal of Japanese Studies, 8: 2 (Summer 1982), pp. 230-1; and The Japanese Question, chs. 5, 6, 7.
} 
growing Japanese pacifism is evident by the increasing Japanese opposition toward the revision of Article 9 of the Constitution (see Table 2). As polls revealed, major shifts in Japanese attitudes toward the United States in general and the US-Japan security treaty in particular have taken place in the last four decades (Table 3).

What has been less noted by students of Japanese politics and foreign policy is the impact of the emergence of this new Japanese security culture on Japanese political structure. As the Yoshida doctrine has taken hold in the belief systems of the Japanese populace, it has also increasingly been accepted by the majority of Japanese political elites. The elites' socialisation led to the significant transformation of Japanese political structures and processes. This can be seen in two dimensions. The first dimension is the gradual expansion of centrists within the Liberal Democratic Party (LDP). While the LDP was polarised between centrists and the right-conservatives on the issues of armed neutrality versus alignment, there emerged a centrist dominance in the LDP by the late 1960s. A survey published in 1958 indicated that a slight majority (52 per cent) of LDP Diet members were in favour of Japan's neutrality in the Cold War. Only 37 per cent favoured Japan's military alignment with the United States. In comparison, a 1968 poll revealed that 87 per cent of the LDP Diet members

Table 1. Japanese attitudes toward the Constitution.

\begin{tabular}{lcc}
\hline \hline & 1955 & 1987 \\
\hline $\begin{array}{l}\text { Percentage of those who liked } \\
\text { the constitution }\end{array}$ & 21 & 58 \\
\hline \hline
\end{tabular}

Source: Adapted from various issues of Asahi Nenkan.

Table 2. Japanese attitudes toward Article 9 of the Constitution.

\begin{tabular}{lll}
\hline \hline & 1955 & 1984 \\
\hline $\begin{array}{l}\text { Percentage of people opposing } \\
\text { the revision of Article 9 }\end{array}$ & 42 & 78 \\
\hline \hline
\end{tabular}

Source: Adapted from various issues of Asahi Nenkan.

Table 3. Japanese attitudes toward the US-Japan Security Treaty (percentages).

\begin{tabular}{lllll}
\hline \hline & 1960 & 1969 & 1978 & 1993 \\
\hline Good for Japan & 36 & 37 & 49 & 52 \\
Not good for Japan & 24 & 34 & 13 & 21 \\
No opinion & 40 & 29 & 38 & 27 \\
\hline
\end{tabular}

Source: Adapted from Asahi Nenkan, and Asahi Shimbun, 29 May 1990, p. 3. 
favoured the continuation of the US-Japan security treaty. ${ }^{52}$ A careful analysis of factional change further lends evidence to the emergence of the centrist dominance in the LDP. Over the years, those factions that were opposed to the Yoshida doctrine have gradually disappeared or been marginalised (the Ono, Fujiyama, and Matsumura factions). Those factions that were either offshoots of the Yoshida faction led by Yoshida Shigeru himself (such as the Tanaka, Ohira and Fukuda factions) or have softened their opposition to the Yoshida doctrine (such as the Nakasone faction) have survived and thrived. The three largest factions in the LDP have been the Sato faction, the Ikeda faction, the Fukuda faction, and their respective successor factions, which have been closely associated with the Yoshida faction and comprised the so-called mainstream conservatives (Hoshuhonryu). ${ }^{53}$

The second dimension is the gradual expansion of the LDP itself and the emergence of the LDP as the perpetual ruling party (the so-called ' 1955 system'). While the JSP mounted a formidable challenge to the centrist foreign policy programme in the 1950s and early 1960s, the JSP was relegated to perpetual minority party status after the late 1970s. The breakup of the LDP after 1993 and the emergence of new political parties had not changed the centrist dominance as evidenced in Ozawa Ichiro's failure to implement his nationalistic foreign policy agenda. Rather, it can be argued that the centrist dominance has further expanded since 1993. This is indicated in the gradual marginalisation of the Democratic Socialist Party of Japan (DSPJ, successor to the JSP), the DSPJ's alliance with the LDP in a coalition government in 1994 (which suggested the DSPJ's open embrace of the Yoshida doctrine), and the emergence of the Democratic Party of Japan (which broadly endorsed the centrist foreign policy line). ${ }^{54}$

The reasons for the emergence of the centrist dominance inside the LDP and the LDP's dominance over opposition parties are complicated. The multiple-seat electoral system may have played a role. Moreover, generational change inside the LDP might have also contributed to it. ${ }^{55}$

Nonetheless, an equally, if not more, important cause for the emerging centrist dominance had to do with the gradual embeddedness of the Yoshida doctrine in Japan's security culture. ${ }^{56}$ As theories of political parties suggest, the structure of party systems tends to reflect voters' attitudes toward critical issues. Changes in the voters' attitude toward critical issues tend to result in the major transformation of political structures and processes. ${ }^{57}$ It has been the defence-related issues (specifically the US-Japan security treaty and the status of Self-Defense Forces) that have been critical in shaping Japanese voting behaviours and hence party systems, giving rise to the conservative-progressive confrontation and the LDP's perpetual dominance. ${ }^{58}$

52 These figures draw on Lloyd Free, Six Allies and A Neutral (Glencoe, IL: The Free Press, 1959), pp. 42 and 51; and Frank Langdon, 'Japanese Liberal Democratic Factional Discord on China Policy’, Pacific Affairs, XLI: 3 (1968), pp. 411-12.

53 Ito Masaya, Jiminto Senkokushi (Tokyo: Asahi Sonorama, 1983), ch. 1.

54 Otake Hideo, 'Political Realignment and Policy Conflict', in Otake (ed.), Power Shuffles and Policy Processes (Tokyo: Japan Center for International Exchange, 2000), pp. 138-47. Masayuki Tadokoro, 'The End of Japan's 'Non-Decision' Politics', Asian Survey, 34: 11 (November 1994), pp. 1004-5.

55 Masumi, Gendai Seiji, p. 149.

56 Schaller, Altered States, p. 169.

57 Maurice Duverger, Political Parties (Paris: Armand Colin, 1951), ch. 2. Walter Burham D, Critical Elections and the Mainsprings of American Politics (New York: W.W. Norton, 1970).

58 Otake, 'Political Realignment and Policy Conflict', p. 128. 
Table 4. Political attitudes of party supporters in Japan (percentages).

\begin{tabular}{lccccc}
\hline \hline Year & 1964 & 1970 & 1974 & 1986 & 1990 \\
\hline $\begin{array}{l}\text { LDP supporters favouring Japan's } \\
\text { integration into the West }\end{array}$ & 83 & 82 & 80 & 88 & 90 \\
$\begin{array}{l}\text { JSP supporters favouring Japan's } \\
\text { integration into the West }\end{array}$ & 35 & 27 & 27 & 49 & 43 \\
\hline
\end{tabular}

Source: Adapted from Miyake Ichiro, 'Ichito Yui Seitosei no Tenkai to Gaiko Kihon Rosen ni Kansuru Ishiki Patan', Nenpo Seijigaku, 1994, p. 186.

Public opinion surveys have also provided evidence on the congruence between the LDP's political strength and voters' defence policy preferences. As Table 4 shows, an overwhelming majority of the LDP supporters consistently endorsed Japan's integration into the US-led Western alliance between the mid-1960s and the late 1990s. This implies that the overwhelming majority of the LDP supporters supported the LDP because of the LDP's pro-US foreign policy. ${ }^{59}$ When centrist public opinion prevailed over rival public opinions in the ideological battle, the centrist politicians who were elected by centrist-inclined voters would have naturally outnumbered the opponents of centrism. ${ }^{60}$

In short, it was the deliberate American and Japanese policies and the external events caused intentionally or unintentionally by the United States, such as the occupation of Japan, the 1960 security treaty crisis, and Japan's rapid economic growth that have led to the emergence of the new Japanese security culture and the resultant dominance of pro-American centrists both inside and outside the LDP.

\section{The effects of the cultural transformation on American hegemony}

Having demonstrated the political dominance of centrists both at the interparty and intraparty levels as a result of the Japanese mass public's socialisation with American hegemonic ideas, the next step is to show that the political transformation does have an important impact on Japan's hegemonic cooperation with the United States. The following section provides some evidence to this effect by examining the foreign policymaking process with regard to two important issues of postwar Japan's China policy. The illustration of the effect of political transformation necessitates two steps. First, it is necessary to show that the dominance of centrists at the interparty level (namely, the long-time dominance of the LDP) has had a constraining effect on Japan's hegemonic cooperation with the US on China policy, despite opposition

59 Ibid., pp. 219-20.

60 Other studies have taken note of important effects of centrist public opinion on Japanese defence policy and especially electoral politics during the 1960s and 1970s. See Kosaka, 100 Million Japanese, p. 202; and Thomas R.H. Havens, Fire Across the Sea (Princeton, NJ: Princeton University Press, 1987), pp. 51-2. Also Packard, Protest in Tokyo, pp. 325-6. 
parties' objections. The constraining effect of the long-standing dominance of the LDP in Japanese politics until 1993 had been very obvious and well documented, as the LDP dominance enabled the LDP to practically ignore the opposition parties' voice with regard to China. ${ }^{61}$ The constraining effect of the dominance of the centrists on China policy at the interparty level after 1993 may become doubtful because of the LDP's demise as a perpetual ruling party, and hence warrants some examination. Second, it is also necessary to show that the dominance of centrists at the intraparty level has had an important constraining effect on Japan's pro-US China policy despite the opposition of rival LDP Diet members. As scholars have aptly documented, factional politics within the LDP had been the centre of the political power struggle within the LDP and the locus of the foreign policymaking process in Japan prior to 1993 because of the LDP's perpetual dominance. To a large extent, factional politics inside the LDP reflect the ideological struggle between the centrists and right conservatives. ${ }^{62}$ Nonetheless, after the LDP's collapse in 1993, the locus of the foreign policymaking process has shifted from the intraparty arena to the interparty arena as the interparty alignment and realignment have become indispensable for maintaining majority political support. While public opinion on Japan's China policy may influence official China policy, public opinion may not be as important a determinant of Japan's China policy as factional politics in the LDP and interparty politics because public opinion on China policy may be very similar to the elites' opinion on China policy as a result of postwar cultural transformation.

The analysis below arrives at two preliminary conclusions. First, in the pre-1993 period, the centrist dominance within the LDP in the form of factional coalition had constrained the Japanese ruling elites' China policy and ultimately contributed to Japan's close cooperation with the United States on Japan's peacemaking with China in 1978. Second, in the post-1993 period, the centrist dominance in the form of interparty coalition between the LDP and other centrist parties has also greatly constrained Japan's China policy and contributed to Japan's reluctant cooperation with the United States with regard to the Taiwan question.

\section{Japan's peacemaking with China}

Postwar Japan's security dependence on the United States has forced Japan to subordinate its China policy to the dictate of American anti-communist containment strategy in East Asia. A few months after the signing of the security treaty with the United States, Japan was under strong American pressure to deny its diplomatic recognition to the newly established People's Republic of China (PRC), which was at war with the United States in Korea. Instead, Japan recognised the govern-

61 Chae-Jin Lee, Japan Faces China: Political and Economic Relations in the Postwar Era (Baltimore, MD: Johns Hopkins University Press, 1976).

62 Donald C. Hellmann, Japanese Foreign Policy and Domestic Politics: The Peace Agreement with the Soviet Union (Berkeley, CA: University of California Press, 1970). Also Kent E. Calder, 'Japanese Foreign Economic Policy Formation: Explaining the Reactive State', World Politics, XL: 4 (July 1987), pp. 517-41. 
ment of the exiled Republic of China in Taiwan (ROC) as the legitimate government of China by signing a peace treaty with ROC. Japan's non-recognition policy toward China did not change until 1972 when Prime Minister Tanaka Takuei travelled to China to normalise Japan's diplomatic relations with China and sever Japan's formal relations with ROC. There, Tanaka committed Japan to unequivocally recognise that there is only one China and that Taiwan was a part of China. In return, Beijing acquiesced to Japan's unofficial relations with Taiwan. ${ }^{63}$

In late 1974, the government of PRC and the Tanaka government formally started official negotiations on the signing of the long-delayed peace treaty between Tokyo and Beijing. ${ }^{64}$ As soon as the Miki government reopened bilateral peace negotiations with China in January 1975, the negotiations went into an impasse over the so-called 'anti-hegemony' clause. The Chinese government insisted that a clause stating that the two countries were uniformly opposed to a third country establishing hegemony in East Asia be inserted in the peace treaty. As the tensions in Sino-Soviet relations heightened in the early 1970s, China hoped to enlist Japan as a potential anti-Soviet ally through the peace treaty. ${ }^{65}$

The Miki government had hoped to rely on the new Sino-Japanese peace treaty to strengthen bilateral relations, improve Japan's security environment and reduce Japan's security dependence on the United States in light of the gradual American disengagement from Southeast Asia. Nonetheless, the Miki government could not accept the anti-hegemony clause for two reasons. First, as Washington had kept its diplomatic and military ties with ROC and refused to recognise China diplomatically at this time despite Nixon's historic trip to China in 1972, Miki Takeo feared that the inclusion of the clause, which was symbolic of close Sino-Japanese relations, might upstage US China policy. ${ }^{66}$ Moreover, it feared the inclusion of the clause would put Japan-Soviet relations in jeopardy at the time when Tokyo and Moscow were negotiating a peace treaty to settle bilateral territorial disputes in the Northern islands. ${ }^{67}$

In December 1975, Fukuda Takeo replaced Miki as the new prime minister as a result of Fukuda's factional alliance with the factions led by Tanaka and Ohira Masayoshi respectively. Ohira was instrumental in helping Tanaka to push for Japan's normalisation with China in $1972 .{ }^{68}$ The Fukuda government faced a more unfavourable international environment. Tokyo's relations with the Soviet Union continued to deteriorate as they were bogged down in Japan-Soviet peace negotiations and disputes over fishery rights. Worst still, the new Carter administration was calling for the withdrawal of American troops from South Korea at the time when Japan faced a more menacing Soviet threat and needed American military protection more than ever. Encouraged by the emergence of political stability in China and the country's adoption of economic modernisation as the top policy priority in early 1977, the pro-China centrists in the LDP, mainly from the Tanaka and Ohira

63 Lee, Japan Faces China.

64 Curtis, The Japanese Way of Politics, p. 162; also Ito, Jiminto Senkokushi, ch. 8-11.

65 Robert Bodeski, The Fragile Entente: The 1978 Japan-China Peace Treaty in A Global Context (Boulder, CO: Westview, 1983), p. 62.

66 Asahi Shimbun, 17 April 1975, p. 3.

67 Nagano Nobutoshi, Tenno to Toshohei no Akushu: Jitsuroku Nitchu Kosho Hishi (Tokyo: Gyosei Mondai Kenkyusho, 1983), ch. 4.

68 Ibid., ch. 5. 
factions, hoped to strengthen Japan's relations with China to counter their common enemy, the Soviet Union, and did not believe that such a policy would undermine Japan's relations with the United States. Hence the pro-China forces soon called for the reopening of treaty negotiations with China. ${ }^{69}$ The pro-China gestures were supported by the business community which saw an early conclusion of the peace treaty as a necessary step to strengthen bilateral economic relations. ${ }^{70}$ On 20 October 1977, more than one hundred pro-Beijing LDP Diet members, along with many Diet members of opposition parties, formed the Citizens' Consultative Committee for Promoting the Sino-Japanese Peace Treaty. ${ }^{71}$

Alarmed by the growing momentum of political support for the peace treaty, many LDP Diet members (mainly from the Fukuda faction and the Nakasone faction) stepped up their opposition to an early peace treaty because of their ideological affinity with Taiwan and concern about the negative impact on US-Japan relations. ${ }^{72}$ Fukuda was caught between the pro-China groups and the pro-Taiwan groups. On the one hand, moving forward with the reopening of peace negotiation would not only stabilise his coalition with the Tanaka-Ohira factions and boost his political standing for LDP presidential re-election in December 1978, but also greatly strengthen Japan's relations with China as a counterweight to the Soviet threat in the wake of the decline of American presence in Asia. ${ }^{73}$ On the other hand, he could not afford to alienate many supporters within his own faction and the Nakasone faction who were cautious about the peace treaty. In early March of 1978, under the prodding of new foreign minister Sonoda Sunao, who was a strong advocate of Japan's close security relations with China, the Fukuda government drafted a compromising proposal. The proposal was to include the 'anti-hegemony' clause in the main text of the treaty, but at the same time insert a 'third country' clause to disclaim that the 'anti-hegemony' clause was directed against any specific third country. ${ }^{74}$

Fukuda's policy plan was thwarted when a large number of Chinese fishing boats were found near the disputed Senkaku (Diaoyu) island on 12 April. The Chinese presence in the disputed island lent support to the pro-Taiwan LDP members, who had sought to use the incident to prevent the signing of the peace treaty. ${ }^{75}$ Once again, the resumption of peace treaty negotiations was deadlocked in the LDP as the issue became politicised in the factional power struggle. ${ }^{76} \mathrm{~A}$ poll conducted on 12 April revealed that 158 LDP Diet members opposed the immediate reopening of peace treaty talks with China, as opposed to 112 LDP Diet members who supported the peace treaty talks. ${ }^{77}$

It was not until a major change occurred in American policy toward China that the deadlock was finally broken. In the wake of Soviet global expansion in Angola and other parts of the world, and the lack of progress in the second round of the

69 Lee, Japan Faces China, p. 130.

70 Furusawa Kenichi, Nitchu Heiwa Yuko Joyaku: Showa hishi (Tokyo: Kodansha, 1988), p. 50.

71 Ibid., p. 77.

72 The Japan Times, 2 November, 1977, p. 1.

73 Ito, Jiminto senkokushi, ch. 17,18.

74 Nagano, Tenno to Toshohei, ch. 6.

75 Ibid, ch. 6.

76 Ito, Jiminto senkokushi, ch. 19.

77 Furusawa, Nitchu Heiwa Yuko Joyaku, p. 130. 
US-Soviet Strategic Arms Limitation Talks, the Carter administration began to view China as a potential counterweight to the Soviet threat and set out to pursue an early normalisation of Sino-US diplomatic relations in early $1978 .{ }^{78}$ On his trip to Washington in early May, Fukuda's resolve to reopen treaty talks with China was strengthened as President Carter lent his tacit support to Fukuda on the treaty. ${ }^{79}$ Fukuda was further encouraged by Zbigniew Brzezinski, National Security Advisor, in late May 1978. On his way back from China where he informed Beijing of an imminent US policy change, Brzezinski stopped by in Tokyo and made it clear to Fukuda that the United States did not object to the inclusion of the 'anti-hegemony' clause in the peace treaty. ${ }^{80}$ The Carter-Fukuda meeting and the Brzezinski trip greatly facilitated Fukuda's intraparty consensus-building process on China policy change. Fukuda soon reopened treaty negotiations and concluded the peace treaty in August 1978.

\section{Taiwan and the revision of the US-Japan security cooperation guidelines}

Japanese attitudes toward China have undergone notable change in recent years as a result of China's rapid international ascendancy. Such an attitudinal change has subtly affected Japan's China policy and its cooperation with the United States. Some Japanese strategic analysts have come to view China as a potential threat to Japan because of China's nuclear missiles. Especially, they see China as posing an indirect threat to Japan through disrupting Japanese maritime transportation in the South China Sea, as three-fourths of Japan's oil imports are shipped annually through the Malacca Strait. ${ }^{81}$ The Taiwan issue has re-emerged as a bone of contention in Sino-Japanese relations in this context. Despite Tokyo's reluctance to provoke Beijing over the Taiwan question, new developments in US-Japan relations have changed Tokyo's calculus over Taiwan. These are the revision of the 1978 Guidelines for US-Japan security cooperation in 1997 and the passage of three related defence laws in May 1999.

The 1978 guidelines were drafted with the Soviet threat in mind. Under the 1978 guidelines, Japan was obliged to support American military operations only in the event of a direct military attack against Japan. The end of the Cold War has raised the question about the relevance of the US-Japan security treaty in general, and the guidelines in particular, now that there is no major power posing a direct threat to Japan. To preserve the US-Japan security treaty in the post-Cold War period, the Clinton administration intended to make the alliance more relevant in coping with potential instabilities in East Asia such as the conflicts in the Korean peninsula, the Taiwan Strait, and the South China Sea, which may pose indirect threats to Japan. ${ }^{82}$

\footnotetext{
78 Harry Harding, A Fragile Relationship: The United States and China Since 1972 (Washington, DC: Brookings Institution, 1992), pp. 80-120.

79 The Japan Times Weekly, 13 May 1978, p. 1.

80 Zbigniew Brzezinski, Power and Principle: Memoirs of the National Security Adviser, 1977-1981 (New York : Farrar, Straus, Giroux, 1983), p. 218.

81 The Japan Times, 4 January 1996, p. 1.

82 Joseph Nye, 'The Case for Deep Engagement', Foreign Affairs, 74: 4 (August 1995), pp. 90-102.
} 
In September 1997, the two governments released the revised defence guidelines. Because of Japan's constitutional ban on the right to collective self-defence, Japan's commitment to support American military operations was restricted to logistical areas only, such as rescue operations, granting the use of military and civilian facilities to US aircraft and vessels, and mine-sweeping. Following the publication of the revised defence guidelines, the Hashimoto government submitted three defence bills to the Diet in order to provide a legal basis for the Japanese Self-Defence Forces (SDF) to undertake these new comitments. ${ }^{83}$ The three defence bills were held up in the Diet because of controversial issues raised by the revised guidelines and the three defence bills.

The release of the revised defence guidelines and the Diet's deliberation over the three bills generated intense debate among Japanese across the political spectrum. The Taiwan issue became a controversial issue arising from the revised guidelines, as Taiwan could fall within their geographical scope. Based on the new guidelines, Japanese rear area support will cover military emergencies in 'areas surrounding Japan'. Both American and Japanese officials stressed that 'areas surrounding Japan' is not a geographic concept, but a 'situational concept'. While the Taiwan Strait is not explicitly covered in the new guidelines, the Taiwan Strait is one of the most likely areas surrounding Japan where a military emergency may arise in respect of the heightening conflict between Mainland China and Taiwan.

The Japanese are divided on this issue. On the one hand, many Japanese analysts and policymakers fear that the inclusion of Taiwan may provoke Beijing and worsen the already fragile relations between the two countries. They believe Japan has no legal basis on which to get involved in the Taiwan Strait as Japan has recognised Taiwan as part of China since $1972 .{ }^{84}$ Moreover, they fear that the inclusion of Taiwan may drag Japan into an unwanted war with China, which may place Japan at the mercy of China's nuclear missiles. ${ }^{85}$ As the Asahi Shimbun editorial on 24 September 1997 warned, 'the new guidelines must not be set up in such a way that Japan automatically becomes a combatant in America's wars' ${ }^{86}$

On the other hand, many Japanese analysts and officials supported the inclusion of Taiwan in the new guidelines. For example, in August 1997, Japan's Chief Cabinet Secretary Kajiyama Seiroku remarked that the guidelines naturally cover the Taiwan Strait. Two reasons for such support can be identified. First, some believe that the inclusion of Taiwan into the revised guidelines is in Japan's national interest, as it may deter China's military action in the Taiwan Strait. ${ }^{87}$ Second, the revised guidelines have raised the stakes for Tokyo as Japan's more active role in the Taiwan Strait seems to have been linked with the stability of the US-Japan security treaty. This is because Tokyo's logistical support will be critical for the successful execution of American military operations in the Taiwan Strait. Japan's failure to carry out its military commitment under the revised guidelines will surely jeopardise US-Japan

83 Barbara Wanner, 'Debate on Guidelines Bills and Japan's Defense Role Picks Up Steam', JEI Report, no. 15A, 16 April 1999, p. 5.

84 Yabuki Susumu, 'Reading Beijing's Foreign Policy', Japan Echo (Spring 1996), p. 35.

85 The Japan Times, 4 January 1996, p. 4.

86 Cited in Japan Echo, December 1997, p. 26-7.

87 Tanaka Hitoshi, 'An Inside look at the Defense Guidelines Review', Japan Echo, December 1997, p. 31 . 
relations. ${ }^{88}$ Thus, as one American official put it bluntly, 'if Americans and Chinese are killing each other' over Taiwan, and 'Japan doesn't support us, the alliance is dead'. ${ }^{89}$ This remark clearly showed the strong pressure that Washington has placed on the Japanese government for the inclusion of Taiwan into the revised guidelines. As the US-Japan security treaty has become the foundation of postwar Japanese foreign policy, the Japanese government cannot allow the Taiwan issue to destroy the bilateral security treaty.

Naturally, Beijing has viewed the revised guidelines with great concern. It is worried that the revision of the guidelines was a step toward a concerted USJapanese strategy to contain China. It strongly opposes the inclusion of Taiwan into the guidelines. ${ }^{90}$ During Chinese president Jiang Zemin's visit to Tokyo in November 1998, Jiang pressed Tokyo for a private acknowledgement that the revised security guidelines do not cover Taiwan. The newly inaugurated Prime Minister Keizo Obuchi only gave a verbal pledge that Japan would not support Taiwan's independence. ${ }^{91}$

Upon his assumption of office, Obuchi made the passage of the three bills one of his top policy priorities and formed a political alliance with the Liberal Party led by Ozawa Ichiro, which enabled him to secure majority support in the lower house of the Diet. Separately Obuchi also brokered a deal with the New Komeito (New Clean Government Party) in order to secure majority support for the bills in the upper house. While the Liberal Party favoured a more active Japanese role in the revised guidelines, the bulk of Diet members of the LDP and the New Komeito favoured a more restricted Japanese role in the revised guidelines, in response to the public concern that these may contravene the constitutional ban on Japan's right to collective self defence and provoke China. In the end, the three-party coalition agreed that the revised bills would restrict Japanese logical support to the 'situations which, if remained untouched, may bring about direct armed attack against Japan'. This modification confines Japanese back-up support to a highly intense conflict that poses an imminent threat to the security of the Japanese home islands. Moreover, the coalition government also inserted in the revised defence bills a provision that stipulates prior Diet approval for the SDF's logistical support in times of emergency. The Diet's failure to approve an SDF operation would result in recalling the SDF from emergency areas. With these qualifications, both houses of the Diet passed the bills in late May 1999, which signified once again Japan's continued cooperation with the United States on China policy along the Yoshida foreign policy line, undergirded by the political dominance of the centrists at the interparty level. The argument that Japan's China policy has departed from the Yoshida doctrine in recent years is premature. $^{92}$ It failed to see that such centrist foreign policy has strong societal and cultural foundations and cannot be changed easily without earth-shattering events. ${ }^{93}$

88 Thomas J. Christensen, 'China, the US-Japan Alliance, and the Security Dilemma in East Asia', International Security, 23: 4 (Spring 1999).

89 Susan V. Lawrence, 'Miles to Go', Far Eastern Economic Review, 26 November 1998, p. 23.

90 Christensen, 'China, the US-Japan Alliance, and the Security Dilemma in East Asia.' Also Banning Garrett and Bonnie Glaser, 'Chinese Apprehensions about Revitalization of the US-Japan Alliance', Asian Survey, April 1997, pp. 383-402.

91 Landers and Lawrence, 'Sorry, No Apology', Far Eastern Economic Review, 10 December 1998, p. 21.

92 Michael J. Green and Benjamin L. Self, 'Japan's Changing China Policy: From Commercial Liberalism to Reluctant Realism', Survival, 38: 2 (Summer 1996), pp. 35-58.

93 Otake, 'Political Realignment and Policy Conflict', pp. 138-44. 


\section{Conclusion}

This article seeks to conceptualise the relations between the stability of hegemony and the hegemon's ability to shape the security culture and hence politics of secondary states, and offers a preliminary test of the four hypotheses by examining Japan's relations with the United States on China policy. As it postulates, a hegemon's material and normative powers may help to induce the socialisation of the mass public in secondary states with the hegemonic conceptions of world order, state identities, and the underlying ideologies, which in turn may lead to changes in secondary states' political structures in ways conducive to the maintenance of hegemony. As the Japanese case clearly illustrates, the socialisation of the Japanese mass public with the Yoshida doctrine has contributed to the maintenance of US hegemony through the creation of a pro-US permanent ruling party (the LDP) and the dominance of the centrists in the LDP, which served as political constraints compelling the ruling elites to continue cooperation with the United States based on the Yoshida doctrine, in spite of the decline of American material power. 